Altai State University

WWW.asu.ru

ISSN 2412-1908

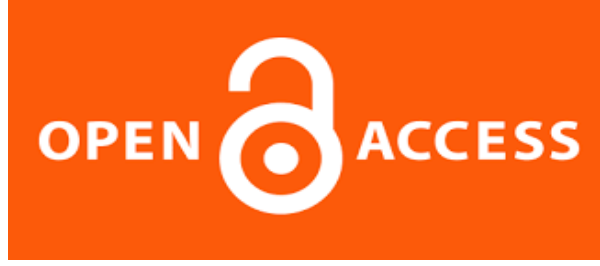

Acta Biologica Sibirica, 2018, 4(3), 130-143

\title{
Comparative analysis of the vertical distribution of the Noctuoid moths (Lepidoptera) within the central parts of the mountain ridges Kirgizsky, Dzhumgaltoo and Fergansky: preliminary results
}

\author{
S.K. Korb \\ Russian Entomological Society, Nizhny Novgorod Branch, P.O. Box 97, Nizhny Novgorod 603009 Russia \\ email: stanislavkorb@list.ru
}

\begin{abstract}
The preliminary results of the comparative analysis of the vertical distribution within the Noctuoid moths of the central parts of the mountain ridges Kirgizsky, Dzhumgaltoo and Fergansky are presented. Within all three ridges 346 species of Noctuoid moths were detected: 246 species in Kirgizsky Mts., 210 species in Dzhumgaltoo Mts. and 164 species in Fergansky Mts. The vertical distribution as follows: lowlands of Kirgizsky Mts. 134 species, Dzhumgaltoo Mts. 85 species, Fergansky Mts. 93 species; middle mountains of Kirgizsky Mts 114 species, Dzhumgaltoo Mts. 191 species, Fergansky Mts. 125 species; highlands of Kirgizsky Mts. 52 species, Dzhumgaltoo Mts. 96 species, Fergansky Mts. 50 species; superhighlands of Kirgizsky Mts. 9 species, Dzhumgaltoo Mts. 17 species, Fergansky Mts. 12 species. These faunas not in general nor by the vertical zones are unsimilar, except the lowlands of the Fergansky and Dzhumgaltoo Mts. The arealogical structure of studied fauna comprises 8 types of areas within 2 complexes of areas. As higher located the vertical zone, as lower in it is the amount of species with wide area types; the same is about the fauna's core.
\end{abstract} Key words: vertical distribution, comparative analysis, Noctuoid moths, Tian-Shan

\section{Сравнительный анализ вертикального распределения ноктуоидных чешуекрылых (Lepidoptera: Noctuoidea) центральных частей хребтов Киргизского, Джумгалтоо и Ферганского: предварительные результаты}

\author{
C.K. Корб \\ Русское энтомологическое общество, Нижегородское отделение, а/я 97, Нижний Новгород 603009, \\ Россия email: stanislavkorb@list.ru
}

Приводятся предварительные результаты сравнительного анализа вертикального распределения чешуекрылых ноктуоидного комплекса центральных частей хребтов Киргизского, Джумгалтоо и Ферганского. Для фауны трех хребтов отмечено 346 видов Noctuoidea, из них по хребтам: 246 видов на Киргизском хр., 210 видов на хр. Джумгалтоо и 164 вида на Ферганском хр. Распределение по вертикальным поясам: низкогорья Киргизского хр. 134 вида, хр. Джумгалтоо 85 видов, Ферганского хр. 93 вида; среднегорья Киргизского хр. 114 видов, хр. Джумгалтоо 191 вид, Ферганского хр. 125 видов; высокогорья Киргизского хр. 52 вида, хр. Джумгалтоо 96 видов, Ферганского хр. 50 видов; сверхвысокогорья Киргизского хр. 9 видов, хр. Джумгалтоо 17 видов, Ферганского хр. 12 
Korb, S.K. Analysis of the vertical distribution of the Noctuoid moths.... Acta Biologica Sibirica, 2018, 4(3), 130-143

видов. Фауны обследованных хребтов ни в целом, ни по поясам несходны, за исключением низкогорного пояса хр. Ферганский и Джумгалтоо. Ареалогическая структура фауны состоит из 8 типов ареалов, объединенных в 2 комплекса. Чем выше расположен вертикальный пояс, тем меньше в нем доля видов с обширными ареалами; то же касается и ядра фауны пояса.

Ключевые слова: вертикальное распределение, сравнительный анализ, ноктуоидные чешуекрылые, Тянь-Шань

\section{Введение}

Вертикальное распределение чешуекрылых ноктуоидного комплекса (Noctuoidea sensu Fibiger et al., 2011) на территории Средней Азии до настоящего времени не изучалось. Наиболее очевидные тому причины - ночной образ жизни подавляющего большинства представителей этого семейства (днем летают лишь немногие представители родов Heliothis Ochsenheimer, 1816, Autographa Hübner, 1821, Tyta Billberg, 1820, Drasteria Hübner, 1818, Acontia Ochsenheimer, 1816), а также несовершенство существовавшей методики ночного сбора, не позволяющей за один раз охватить сборами сколько-нибудь значимый участок вертикального профиля. Сборы ночных летающих насекомых обычно проводятся на свет стационарно установленных мощных ртутно-кварцевых ламп; при этом сборщик не имеет возможности оперативно перемещать место лова в ночное время, так как зависит от источника электричества (обычно это бензиновые электрогенераторы) и стационарно установленного экрана (полотна растянутой белой материи, выполняющего функции отражения света УФ-лампы и посадочной площадки для прилетающих насекомых). Кроме того, для исследования вертикального распределения ночных насекомых сбор на ртутно-кварцевые УФ-лампы неприменим, так как свет этих ламп привлекает насекомых с большого расстояния (до нескольких километров), соответственно, собираемая фауна не может быть однозначно соотнесена с тем вертикальным поясом или биотопом, в котором располагается место лова (Korb, Matov, 2016).

Все перечисленные выше проблемы решаются использованием переносных светоловушек и винных ловушек автономного действия с небольшим (50-100 м) радиусом привлечения. В 2016 г. была опубликована первая работа о вертикальном распределении совкообразных чешуекрылых Средней Азии (центральной части северного склона Киргизского хр.) (Korb, Matov, 2016).

Нами с 2013 по 2018 гг. проводились исследования вертикального распределения совкообразных чешуекрылых с использованием светоловушек и винных ловушек на территории Северного, Внутреннего и Западного Тянь-Шаня. Докладываем предварительные результаты этой работы в настоящей статье.

\section{Материал и методы}

Исследование проводилось с использованием автономных переносных светоловушек на базе цилиндрических контейнеров (Fry, Waring, 1996) и автономных переносных винных ловушек на базе цилиндрических контейнеров (Саpinera, 2001). В качестве фиксирующего агента использовался тетрахлорэтан. Использовано 5 автономных светоловушек и 2 автономные винные ловушки. Светоловушки оборудовались выключателями на базе фотоэлемента.

Исследованные локалитеты:

Северный Тянь-Шань: центральная часть Киргизского хребта, ущелье Ала-Арча (северный макросклон), 27 км южнее г. Бишкек. От входа в ущелье (высота 1200 м н.у.м. (далее - просто м)) до кордона заповедника (2200 м) проходит автодорога общей протяженностью 22 км, что делает весьма комфортной установку и снятие светоловушек до высоты 2200 м. Ловушки на больших высотах устанавливались во время пеших экскурсий.

Внутренний Тянь-Шань: центральная часть хр. Джумгалтоо, долина р. Кекемерен (северо-западный склон). Установка ловушек на вертикальном профиле производилась во время пеших экскурсий.

Западный Тянь-Шань: центральная часть Ферганского хр., перевал Урум-Баш (юго-западный склон). От подножия хребта (1200 м) до седловины перевала (3036 м) проходит автодорога. Общая протяженность автодороги составляет от входа в ущелье до самой высокой точки около 35 км, что делает весьма комфортной установку и снятие светоловушек до самой седловины.

Светоловушки устанавливались с высотными интервалами около 500 м: подножие (высота 900-1200 м), горные степи (1500-1600 М), средняя часть (1900-2000 М), отметка 2500 м ( \pm 50 м), высокогорье и сверхвысокогорье (3000-3300 м). Таким образом, исследования охватили все вертикальные пояса (о принятой в настоящей работе схеме вертикальной поясности см.: Корб, 2012; эта схема включает вертикальные пояса: низкогорный (800-1500 м), среднегорный (1500-2400 м), высокогорный (2400-3100 м) и сверхвысокогорный (свыше 3100 м)). Контроль высоты установки светоловушек проводился с помощью барометрического высотомера прибора спутниковой навигации GPS Garmin Oregon 450. Исследования проводились в мае сентябре 2014-2018 гг., по 3 маршрутных выхода ежемесячно. Кроме того, низкогорная фауна совок центральной части Киргизского хр. изучалась стационарно в окр. г. Бишкек (населенные пункты Кок-Жар, Сарбан, Ала-Тоо, Арашан) на протяжении всего полевого сезона 2014-2018 гг. (более 2000 ловушко-ночей). Собрано и обработано более 42000 экземпляров чешуекрылых ноктуоидного комплекса. 
Определение материала проводилось в основном А.Ю. Матовым (Зоологический институт РАН, С.Петербург); часть материала определена О. Пекарским (Будапешт, Венгрия). Основная часть материала хранится в коллекции автора; небольшая часть материала передана в Зоологический институт РАН и в коллекцию О. Пекарского. Вычисления производились с использованием программных пакетов Microsoft Excel (версия 2016) и StatSoft Statistica for Windows (версия 10) на базе операционной системы Microsoft Windows 8.1.

В работе использовано понятие ядро фауны (характерные виды фауны), которое, согласно Y.Y. Stshetkin (1981: 857) составляют виды, «...нашедшие в данном поясе или полосе наиболее благоприятные условия для развития, что выражается в их максимальной там численности».

\section{Результаты и их обсуждение}

Основные результаты работы приведены в табл. 1.

Таблица 1. Вертикальное распределение чешуекрылых ноктуоидного комплекса Северного, Внутреннего и Западного Тянь-Шаня

\begin{tabular}{|c|c|c|c|c|c|c|c|c|c|c|c|c|c|c|}
\hline \multirow[t]{2}{*}{ № } & \multirow[t]{2}{*}{ Вид } & \multicolumn{4}{|c|}{ Киргизский хр. } & \multicolumn{4}{|c|}{ хр. Джумгалтоо } & \multicolumn{4}{|c|}{ Ферганский хр. } & \multirow{2}{*}{$\begin{array}{l}\text { Тип } \\
\text { ареала }\end{array}$} \\
\hline & & $\mathbf{H}$ & C & B & CB & $\mathbf{H}$ & C & B & CB & $\mathbf{H}$ & C & B & CB & \\
\hline 1 & Cerura przewalskii (Alphéraky, 1882) & + & - & - & - & + & + & + & - & + & + & - & - & ЗП \\
\hline 2 & Furcula terminata (Wiltshire, 1958) & + & + & - & - & - & + & - & - & - & - & - & - & CA \\
\hline 3 & Notodonta tritophus (Denis et Schiffermüller, 1775) & + & - & - & - & - & - & - & - & - & - & - & - & ЗП \\
\hline 4 & N. ziczac (Linnaeus, 1758) & + & + & - & - & + & - & - & - & - & - & - & - & ЗП \\
\hline 5 & Clostera anachoreta (Denis et Schiffermüller, 1775) & + & + & - & - & - & - & - & - & + & - & - & - & $\Pi$ \\
\hline 6 & C. modesta (Staudinger, 1889) & - & - & - & - & - & $!$ & - & - & - & - & - & - & CA \\
\hline 7 & Hypena rostralis (Linnaeus, 1758) & + & - & - & - & - & - & - & - & - & - & - & - & ЗП \\
\hline 8 & Zekelita ravalis (Herrich-Schäffer, 1851) & + & - & - & - & - & - & - & - & - & - & - & - & ЗП \\
\hline 9 & Z. diagonalis (Alphéraky, 1882) & - & - & - & - & - & + & $!$ & - & - & - & - & - & ТШ \\
\hline 10 & Dicallomera fascelina (Linnaeus, 1758) & + & + & - & - & $!$ & $!$ & - & - & + & + & - & - & $\Pi$ \\
\hline 11 & Euproctis karghalica (Moore, 1878) & + & + & + & - & + & + & + & - & + & $!$ & + & - & CA \\
\hline 12 & Orgyia prisca Staudinger, 1887 & - & - & - & - & - & + & - & - & - & - & - & - & CA \\
\hline 13 & Leucoma salicis (Linnaeus, 1758) & + & + & - & - & + & + & - & - & + & $!$ & - & - & $\Pi$ \\
\hline 14 & Lymantria dispar (Linnaeus, 1758) & + & + & - & - & + & + & - & - & + & $!$ & - & - & K \\
\hline 15 & Carcinopyga proserpina (Staudinger, 1887) & + & + & - & - & + & + & - & - & - & - & - & - & CA \\
\hline 16 & Tyria jacobaeae (Linnaeus, 1758) & + & + & - & - & - & - & - & - & - & - & - & - & ЗП \\
\hline 17 & Lacydes spectabilis (Tauscher, 1806) & $!$ & + & - & - & $!$ & - & - & - & - & - & - & - & $\Pi$ \\
\hline 18 & Arctia intercalaris (Eversmann, 1843) & - & $!$ & + & - & - & - & - & - & - & - & - & - & CA \\
\hline 19 & A. caja (Linnaeus, 1758) & + & + & - & - & + & $!$ & + & - & + & + & - & - & $\Gamma$ \\
\hline 20 & Palearctia glaphyra (Eversmann, 1843) & - & - & + & + & - & - & - & - & - & - & - & - & ТШ \\
\hline 21 & P. gratiosa (Groum-Grshimaïlo, 1890) & - & - & - & + & - & - & - & - & - & - & - & - & CA \\
\hline 22 & P. golbecki Dubatolov, 1996 & - & - & - & + & - & - & - & - & - & - & - & - & ТШ \\
\hline 23 & P. erschoffi (Alpheraky, 1882) & - & - & + & - & - & - & - & - & - & - & - & - & ТШ \\
\hline 24 & Chelis ferghana Dubatolov, 1988 & - & - & - & - & - & + & - & - & - & - & - & - & ТШ \\
\hline 25 & C. strigulosa (Böttcher, 1905) & + & $!$ & - & - & + & + & + & - & - & - & - & - & ТШ \\
\hline 26 & Diacrisia sannio (Linnaeus, 1758) & + & + & - & - & + & + & - & - & + & + & - & - & $\Pi$ \\
\hline 27 & Rhyparia purpurata (Linnaeus, 1758) & - & + & - & - & - & - & - & - & - & - & - & - & $\Pi$ \\
\hline 28 & Eudiaphora turensis (Erschoff, 1874) & $!$ & + & - & - & $!$ & + & - & - & + & + & - & - & CA \\
\hline 29 & Spilosoma urticae (Esper, 1789) & + & - & - & - & - & - & - & - & + & - & - & - & $\Pi$ \\
\hline 30 & Phragmatobia fuliginosa (Linnaeus, 1758) & $!$ & - & - & - & $!$ & + & - & - & $!$ & + & - & - & $\Gamma$ \\
\hline 31 & Pelosia obtusa (Herrich-Schäffer, 1847) & - & - & + & - & - & - & - & - & - & - & - & - & $\Pi$ \\
\hline 32 & Manulea complana (Linnaeus, 1758) & + & - & - & - & + & $!$ & - & - & - & - & - & - & $\Pi$ \\
\hline 33 & M. lutarella (Linnaeus, 1758) & + & - & - & - & + & - & - & - & - & - & - & - & $\Pi$ \\
\hline 34 & Calyptra thalictri (Borkhausen, 1790) & + & - & - & - & - & - & - & - & - & - & - & - & $\Pi$ \\
\hline 35 & Lygephila ludicra (Hübner, 1790) & - & - & - & - & - & + & $!$ & - & + & - & - & - & $\Pi$ \\
\hline 36 & L. craccae (Denis et Schiffermüller, 1775) & + & $!$ & - & - & - & - & - & - & - & - & - & - & $\Pi$ \\
\hline 37 & Autophila asiatica (Staudinger, 1889) & ! & + & - & - & + & + & - & - & $!$ & - & - & - & ЦП \\
\hline 38 & A. gracilis (Staudinger, 1874) & + & + & - & - & - & - & - & - & - & - & - & - & ТШ \\
\hline 39 & A. ligaminosa (Eversmann, 1851) & + & - & - & - & - & - & - & - & - & - & - & - & ЦП \\
\hline 40 & Apopestes phantasma (Eversmann, 1843) & ! & - & - & - & - & - & - & - & - & - & - & - & CA \\
\hline 41 & Eublemma minutata (Fabricius, 1794) & - & - & - & - & - & + & - & - & - & - & - & - & ЗП \\
\hline 42 & E. rosea (Hübner, 1809) & - & + & - & - & - & + & - & - & - & - & - & - & $\Pi$ \\
\hline 43 & E. pannonica Freyer, 1840 & + & + & - & - & + & + & - & - & - & - & - & - & ЦП \\
\hline 44 & E. amoena (Hübner, 1803) & + & + & - & - & + & + & - & - & + & + & - & - & $3 П$ \\
\hline 45 & E. purpurina (Denis et Schiffermüller, 1775) & + & + & - & - & + & - & - & - & - & - & - & - & $3 П$ \\
\hline 46 & E. pulchralis (de Villers, 1789) & + & - & - & - & - & - & - & - & - & - & - & - & $3 П$ \\
\hline 47 & E. pallidula (Herrich-Schäffer, 1856) & + & + & - & - & - & - & - & - & - & - & - & - & $3 П$ \\
\hline 48 & E. conistrota Hampson, 1910 & - & - & - & - & - & $!$ & - & - & - & - & - & - & CA \\
\hline 49 & Odice arcuinna (Hübner, 1790) & + & + & - & - & + & $!$ & - & - & $!$ & + & - & - & ЗП \\
\hline
\end{tabular}




\begin{tabular}{|c|c|c|c|c|c|c|c|c|c|c|c|c|c|c|}
\hline 50 & Phytometra viridaria (Clerck, 1759) & - & - & - & - & - & - & - & - & + & + & - & - & $\Pi$ \\
\hline 51 & Pericyma albidentaria (Freyer, 1841) & + & - & - & - & - & - & - & - & - & - & - & - & ЗП \\
\hline 52 & Acantholipes regularis (Hübner, 1813) & + & - & - & - & - & - & - & - & - & - & - & - & ЦП \\
\hline 53 & Drasteria sculpta (Püngeler, 1904) & + & + & - & - & - & - & - & - & - & - & - & - & ТШ \\
\hline 54 & D. obscurata (Staudinger, 1892) & + & $!$ & + & - & + & + & + & - & + & + & + & - & CA \\
\hline 55 & D. sesquilina (Staudinger, 1888) & - & - & - & - & + & $!$ & - & - & - & - & - & - & CA \\
\hline 56 & D. saisani (Staudinger, 1882) & + & + & + & - & + & + & + & - & + & - & - & - & CA \\
\hline 57 & D. rada (Boisduval, 1848) & - & - & - & - & + & $!$ & - & - & - & - & - & - & ЗП \\
\hline 58 & D. picta (Christoph, 1877) & $!$ & - & - & - & - & - & - & - & - & - & - & - & ЗП \\
\hline 59 & D. caucasica (Kolenati, 1846) & + & $!$ & - & - & + & + & - & - & + & $!$ & - & - & ЗП \\
\hline 60 & Catocala neonympha (Esper, 1805) & + & + & - & - & + & + & - & - & + & + & - & - & ЗП \\
\hline 61 & C. nupta (Linnaeus, 1767) & - & + & - & - & - & + & - & - & - & - & - & - & $\Pi$ \\
\hline 62 & C. afghana Swinhoe, 1885 & + & - & - & - & - & - & - & - & - & - & - & - & CA \\
\hline 63 & C. elocata (Esper, 1787) & + & - & - & - & - & - & - & - & - & - & - & - & $\Pi$ \\
\hline 64 & C. puerpera (Giorna, 1791) & + & + & - & - & - & + & - & - & - & + & - & - & ЦП \\
\hline 65 & Callistege mi (Clerck, 1759) & + & - & - & - & - & - & - & - & - & - & - & - & ЗП \\
\hline 66 & Clytie gracilis (Bang-Haas, 1907) & + & - & - & - & - & - & - & - & $!$ & - & - & - & ЦП \\
\hline 67 & Abrostola agnorista Dufay, 1956 & - & + & - & - & - & - & - & - & - & - & - & - & $3 \Pi$ \\
\hline 68 & A. tripartita (Hufnagel, 1766) & + & + & + & - & - & - & - & - & - & - & - & - & $\Pi$ \\
\hline 69 & Trichoplusia ni (Hübner, 1803) & + & - & - & - & - & - & - & - & - & - & - & - & $\Gamma$ \\
\hline 70 & Euchalcia inconspicua (Graeser, 1892) & - & + & + & - & - & + & + & - & - & + & - & - & CA \\
\hline 71 & E. anthea (L.Ronkay, G.Ronkay et Behounek, 2008) & - & + & + & - & - & + & + & - & - & - & - & - & ТШ \\
\hline 72 & E. herrichi (Staudinger, 1851) & - & + & $!$ & - & - & + & + & - & - & - & - & - & $\mathrm{CA}$ \\
\hline 73 & E. aranka Hacker et Ronkay, 1992 & - & - & + & - & - & - & - & - & - & - & - & - & CA \\
\hline 74 & Polychrysia esmeralda (Oberthür, 1880) & - & + & + & - & - & ! & ! & - & - & - & - & - & $\Gamma$ \\
\hline 75 & Diachrysia chrysitis (Linnaeus, 1758) & + & + & $!$ & - & + & - & - & - & + & - & - & - & $\Pi$ \\
\hline 76 & D. stenochrysis (Warren, 1913) & + & + & + & - & + & + & + & - & - & - & - & - & $\Pi$ \\
\hline 77 & Macdunnoughia confusa (Stephens, 1850) & + & - & - & - & + & - & - & - & - & - & - & - & $\Pi$ \\
\hline 78 & Autographa gamma (Linnaeus, 1758) & + & $!$ & + & - & + & $!$ & + & - & + & + & - & - & $\Pi$ \\
\hline 79 & A. buraetica (Staudinger, 1892) & - & - & - & - & - & - & - & - & - & + & - & - & $\Pi$ \\
\hline 80 & A. camptosema (Hampson, 1913) & + & + & - & - & + & + & - & - & + & - & - & - & ЦП \\
\hline 81 & A. monogramma (Alphéraky, 1887) & - & + & + & - & - & + & ! & - & - & - & - & - & CA \\
\hline 82 & A. bractea (Denis et Schiffermüller, 1775) & - & - & - & - & - & + & + & - & - & - & + & - & $\Pi$ \\
\hline 83 & Cornutiplusia circumflexa (Linnaeus, 1767) & + & + & + & - & - & - & - & - & - & - & - & - & $\mathrm{K}$ \\
\hline 84 & Syngrapha alaica (Rebel, 1906) & - & - & + & + & - & - & + & + & - & - & - & + & CA \\
\hline 85 & Plusia festucae (Linnaeus, 1758) & - & + & + & - & - & + & + & - & - & - & + & - & $\Pi$ \\
\hline 86 & Acontia trabealis (Scopoli, 1763) & + & - & - & - & $!$ & $!$ & - & - & + & $!$ & - & - & $\Pi$ \\
\hline 87 & A. lucida (Hufnagel, 1866) & + & $!$ & - & - & + & + & - & - & + & + & - & - & $3 П$ \\
\hline 88 & Armada clio (Staudinger, 1884) & $!$ & - & - & - & - & - & - & - & - & - & - & - & CA \\
\hline 89 & A. panaceorum (Menetries, 1849) & + & - & - & - & - & - & - & - & - & - & - & - & $3 П$ \\
\hline 90 & Raphia approximata Alphéraky, 1887 & + & + & - & - & + & + & - & - & $!$ & - & - & - & ТШ \\
\hline 91 & Acronicta psi (Linnaeus, 1758) & - & + & - & - & - & + & - & - & - & + & - & - & $\Pi$ \\
\hline 92 & A. centralis Erschoff, 1874 & + & + & - & - & - & - & - & - & - & - & - & - & CA \\
\hline 93 & A. rumicis (Linnaeus, 1758) & + & + & - & - & - & - & - & - & + & - & - & - & $\Pi$ \\
\hline 94 & Simyra nervosa (Denis et Schiffermüller, 1775) & + & + & - & - & - & + & - & - & - & - & - & - & ЦП \\
\hline 95 & Gyrohypsoma sterrha (Staudinger, 1888) & + & - & - & - & - & - & - & - & + & - & - & - & CA \\
\hline 96 & Dismylichia bicyclica (Staudinger, 1888) & $!$ & - & - & - & + & + & - & - & + & - & - & - & CA \\
\hline 97 & Tyta luctuosa (Denis et Schiffermüller, 1775) & + & $!$ & + & - & $!$ & + & + & - & + & ! & + & - & $3 \Pi$ \\
\hline 98 & Cucullia magnifica Freyer, 1849 & - & - & - & - & - & - & - & - & - & + & - & - & ЦП \\
\hline 99 & C. splendida (Stoll, 1782) & - & - & - & - & - & + & ! & - & - & - & + & - & $\mathrm{B} \Pi$ \\
\hline 100 & C. absinthii (Linnaeus, 1761) & + & + & + & - & + & + & + & - & + & + & + & - & ЗП \\
\hline 101 & C. argentea (Hufnagel, 1766) & - & - & - & - & - & + & + & - & - & - & - & - & $\Pi$ \\
\hline 102 & C. cineracea Freyer, 1841 & + & + & + & - & + & + & - & - & - & - & - & - & ЦП \\
\hline 103 & C. infuscata Tshetverikov, 1925 & + & - & - & - & - & - & - & - & - & - & - & - & ВП \\
\hline 104 & C. artemisiae (Hufnagel, 1766) & - & + & + & - & - & - & - & - & - & - & - & - & $\Pi$ \\
\hline 105 & C. xeranthemi Boisduval, 1840 & - & - & - & - & - & - & - & - & - & + & - & - & ЦП \\
\hline 106 & C. lucifuga (Denis et Schiffermüller, 1775) & - & + & - & - & - & + & - & - & - & - & - & - & $\Pi$ \\
\hline 107 & C. umbratica (Linnaeus, 1758) & + & + & - & - & + & + & - & - & + & + & - & - & $\Pi$ \\
\hline 108 & C. inderiensis Herrich-Schäffer, 1856 & + & - & - & - & - & - & - & - & - & - & - & - & ЦП \\
\hline 109 & C. boryphora Fischer de Waldheim, 1840 & + & - & - & - & - & - & - & - & - & - & - & - & ЦП \\
\hline 110 & C. tanaceti (Denis et Schiffermüller, 1775) & + & - & - & - & - & - & - & - & - & - & - & - & ЗП \\
\hline 111 & C. dracunculi (Hübner, 1813) & - & + & - & - & - & + & - & - & - & - & - & - & ЗП \\
\hline 112 & C. turkestana Ronkay et Ronkay, 1987 & - & - & - & - & - & + & - & - & - & - & - & - & CA \\
\hline 113 & C. virgaureae Boisduval, 1840 & - & - & - & - & - & + & + & - & - & - & - & - & ЦП \\
\hline 114 & C. amota Alphéraky, 1887 & - & - & - & - & - & + & + & - & - & - & - & - & ЦП \\
\hline 115 & C. asteris (Denis et Schiffermüller, 1775) & + & + & + & - & + & + & + & - & + & + & + & - & ЗП \\
\hline 116 & C. kurilullia Bryk, 1942 & + & + & + & - & - & - & - & - & - & - & - & - & $\mathrm{B} \Pi$ \\
\hline
\end{tabular}




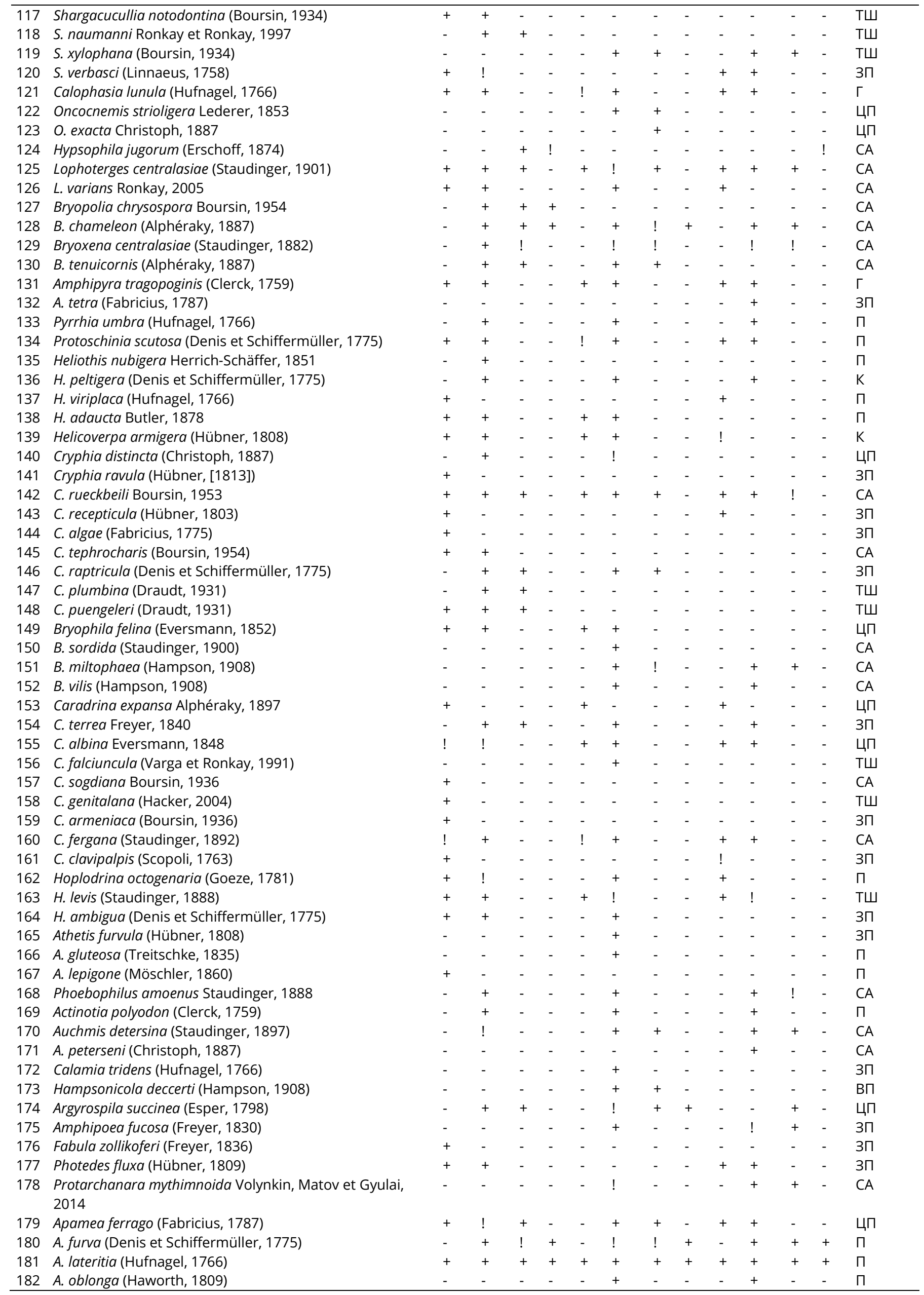




\begin{tabular}{|c|c|c|c|c|c|c|c|c|c|c|c|c|c|c|}
\hline 183 & A. sordens (Hufnagel, 1766) & - & + & - & - & - & + & - & - & - & + & - & - & $\Pi$ \\
\hline 184 & A. remissa (Hübner, 1809) & - & - & - & - & - & + & + & - & - & + & + & - & $\Gamma$ \\
\hline 185 & A. crenata (Hufnagel, 1766) & - & + & + & - & - & + & + & - & - & - & - & - & $\Pi$ \\
\hline 186 & Atrachea cortex (Alphéraky, 1887) & - & + & - & - & - & - & - & - & - & - & - & - & ТШ \\
\hline 187 & Resapamea hedeni (Graeser, 1889) & - & + & + & - & - & - & + & - & - & - & - & - & $\Pi$ \\
\hline 188 & Mesoligia furuncula (Denis et Schiffermüller, 1775) & + & + & - & - & + & + & - & - & + & - & - & - & $\Pi$ \\
\hline 189 & Litoligia literosa (Haworth, 1809) & + & + & - & - & - & + & - & - & - & + & - & - & $\Pi$ \\
\hline 190 & Mesapamea moderata (Eversmann, 1843) & - & - & - & - & - & + & - & - & - & + & - & - & ЦП \\
\hline 191 & M. calcirena (Püngeler, 1902) & - & - & - & - & - & + & - & - & - & + & - & - & ТШ \\
\hline 192 & Episema lederi Christoph, 1885 & $!$ & - & - & - & - & - & - & - & - & - & - & - & ЗП \\
\hline 193 & Turanica haeretica (Püngeler, 1902) & + & - & - & - & - & - & - & - & + & - & - & - & CA \\
\hline 194 & Mesogona oxalina (Hübner, [1803]) & - & + & - & - & - & - & - & - & - & - & - & - & ЗП \\
\hline 195 & Agrochola lychnidis (Denis et Schiffermüller, 1775) & + & - & - & - & - & - & - & - & - & - & - & - & ЦП \\
\hline 196 & A. trapezoides (Staudinger, 1882) & - & - & - & - & - & - & - & - & + & - & - & - & ТШ \\
\hline 197 & Xylena exoleta (Linnaeus, 1758) & + & + & + & - & - & - & - & - & - & - & - & - & $\Pi$ \\
\hline 198 & Eupsilia transversa (Hufnagel, 1766) & + & - & - & - & - & - & - & - & + & - & - & - & $\Pi$ \\
\hline 199 & Enargia staudingeri (Alphéraky, 1882) & - & - & - & - & - & - & - & - & - & + & - & - & ТШ \\
\hline 200 & Cosmia affinis (Linnaeus, 1757) & + & + & - & - & - & + & - & - & - & - & - & - & $\Pi$ \\
\hline 201 & C. subtilis Staudinger, 1888 & - & - & - & - & - & - & - & - & - & $!$ & $!$ & - & ТШ \\
\hline 202 & C. ledereri (Staudinger, 1897) & - & + & - & - & - & + & $!$ & - & - & + & + & - & ТШ \\
\hline 203 & Rhiza laciniosa (Christoph, 1887) & - & - & - & - & + & + & - & - & - & - & - & - & ЦП \\
\hline 204 & Phidrimana amurensis (Staudinger, 1892) & + & - & - & - & - & - & - & - & - & - & - & - & $\Pi$ \\
\hline 205 & Polymixis trisignata (Ménétriés, 1848) & - & + & - & - & - & - & - & - & - & - & - & - & CA \\
\hline 206 & P. acharis (Püngeler, 1901) & - & + & + & - & - & - & - & - & - & + & - & - & ЦП \\
\hline 207 & Eremohadena immunda (Eversmann, 1842) & $!$ & + & - & - & - & + & + & - & - & - & - & - & ЦП \\
\hline 208 & Palaeagrotis inops (Lederer, 1853) & - & - & - & - & - & + & + & - & - & - & - & - & ЦП \\
\hline 209 & Heterographa fabrilis Püngeler, 1909 & + & - & - & - & - & - & - & - & - & - & - & - & ТШ \\
\hline 210 & Dasypolia lama Staudinger, 1896 & + & - & - & - & - & - & - & - & - & - & - & - & ЦП \\
\hline 211 & D. eberti Boursin, 1967 & + & - & - & - & - & - & - & - & - & - & - & - & CA \\
\hline 212 & D. shugnana Varga, 1982 & + & - & - & - & - & - & - & - & - & - & - & - & CA \\
\hline 213 & D. diva Ronkay et Varga, 1990 & + & - & - & - & - & - & - & - & - & - & - & - & CA \\
\hline 214 & Mniotype juldussica (Draudt, 1938) & - & + & + & - & - & - & - & - & - & + & + & - & ТШ \\
\hline 215 & M. leucocyma (Hampson, 1907) & - & - & - & - & - & + & + & - & - & + & + & - & CA \\
\hline 216 & M. lama (Staudinger, 1900) & - & - & + & - & - & - & - & - & - & - & - & - & CA \\
\hline 217 & Orthosia pallidior (Staudinger, 1888) & + & - & - & - & - & - & - & - & - & - & - & - & ТШ \\
\hline 218 & O. incerta (Hufnagel, 1766) & + & - & - & - & - & - & - & - & - & - & - & - & ЗП \\
\hline 219 & O. opima (Hübner, [1809]) & + & - & - & - & - & - & - & - & - & - & - & - & ЗП \\
\hline 220 & Perigrapha centralasiae Bartel, 1906 & + & - & - & - & - & - & - & - & + & - & - & - & CA \\
\hline 221 & P. yasawii Volynkon, Titov et Knyazev, 2014 & + & - & - & - & - & - & - & - & - & - & - & - & ТШ \\
\hline 222 & P. ductana Draudt, 1934 & - & - & - & - & - & - & - & - & + & + & - & - & CA \\
\hline 223 & Egira anatolica (Hering, 1933) & - & - & - & - & - & - & - & - & + & + & - & - & ЗП \\
\hline 224 & Cerapteryx megala (Alphéraky, 1882) & - & - & - & - & - & - & + & $!$ & - & - & + & + & ТШ \\
\hline 225 & Anarta ptochica (Püngeler, 1900) & - & - & - & - & - & - & + & + & - & - & - & - & CA \\
\hline 226 & A. odontites (Boisduval, 1829) & - & - & - & - & - & + & + & + & - & - & - & - & ЗП \\
\hline 227 & A. farnhami (Grote, 1873) & - & - & - & - & - & - & + & + & - & - & - & - & $\Gamma$ \\
\hline 228 & A. dianthi (Tauscher, 1809) & - & - & - & - & - & $!$ & + & - & - & - & - & - & ЗП \\
\hline 229 & A. trifolii (Hufnagel, 1766) & + & $!$ & + & - & + & $!$ & + & - & + & $!$ & + & - & $\Gamma$ \\
\hline 230 & Haderonia arschanica (Alphéraky, 1882) & - & + & $!$ & - & - & + & $!$ & - & - & + & + & - & ТШ \\
\hline 231 & Ctenoceratoda tancrei (Graeser, 1892) & + & + & - & - & + & + & - & - & + & - & - & - & CA \\
\hline 232 & C. graeseri (Püngeler, 1898) & - & - & - & - & - & + & - & - & - & - & - & - & ТШ \\
\hline 233 & Polia bombycina (Hufnagel, 1766) & + & + & - & - & + & $!$ & - & - & + & + & - & - & $\Pi$ \\
\hline 234 & P. serratilinea Ochsenheimer, 1816 & - & + & + & - & - & + & $!$ & - & - & + & - & - & $\Pi$ \\
\hline 235 & P. altaica (Lederer, 1853) & - & + & + & - & - & - & - & - & - & - & - & - & ЦП \\
\hline 236 & Lacanobia w-latinum (Hufnagel, 1766) & + & + & - & - & + & + & - & - & $!$ & - & - & - & 3П \\
\hline 237 & L. contigua (Denis et Schiffermüller, 1775) & - & + & - & - & - & + & - & - & - & + & - & - & $\Pi$ \\
\hline 238 & L. suasa (Denis et Schifffermüller, 1775) & + & $!$ & - & - & + & $!$ & - & - & + & $!$ & - & - & $\Pi$ \\
\hline 239 & L. oleracea (Linnaeus, 1758) & + & + & - & - & - & + & - & - & + & + & - & - & ЗП \\
\hline 240 & L. praedita (Hübner, 1813) & + & + & - & - & - & - & - & - & + & + & - & - & ЦП \\
\hline 241 & Papestra biren (Goeze, 1781) & - & + & + & - & - & - & - & - & - & - & - & - & $\Pi$ \\
\hline 242 & Mamestra brassicae (Linnaeus, 1758) & + & + & - & - & + & $!$ & - & - & + & $!$ & - & - & $\Pi$ \\
\hline 243 & Sideridis rivularis (Fabrucius, 1775) & - & + & + & - & - & - & - & - & - & - & - & - & $\Pi$ \\
\hline 244 & S. unicolor (Alphéraky, 1889) & - & + & - & - & - & + & - & - & - & - & - & - & CA \\
\hline 245 & Conisania leineri (Freyer, 1836) & - & - & - & - & - & + & + & + & - & $!$ & $!$ & + & ЗП \\
\hline 246 & C. vidua (Staudinger, 1888) & - & - & - & - & + & $!$ & - & - & + & + & - & - & CA \\
\hline 247 & Hecatera bicolorata (Hufnagel, 1766) & - & - & - & - & - & $!$ & $!$ & - & - & - & - & - & $\Pi$ \\
\hline 248 & H. dysodea (Denis et Schiffermüller, 1775) & - & + & - & - & - & + & - & - & - & - & - & - & $\Gamma$ \\
\hline 249 & Hadena magnolii (Boisduval, 1829) & - & - & - & - & - & - & - & - & + & + & - & - & ЗП \\
\hline
\end{tabular}




\begin{tabular}{|c|c|c|c|c|c|c|c|c|c|c|c|c|c|c|}
\hline 250 & H. sogdiana Hacker, 1996 & - & - & - & - & + & + & + & - & - & - & - & - & CA \\
\hline 251 & H. humilis (Christoph, 1893) & - & - & - & - & - & - & - & - & + & - & - & - & ЦП \\
\hline 252 & H. albimacula (Borkhausen, 1792) & + & + & - & - & + & + & - & - & $!$ & - & - & - & ЗП \\
\hline 253 & H. intensa Boursin, 1962 & - & + & + & - & - & + & - & - & - & - & - & - & ТШ \\
\hline 254 & H. karagaia (Bang-Haas, 1912) & - & - & - & - & + & + & $!$ & - & + & + & + & - & ТШ \\
\hline 255 & H. perplexa (Denis et Schiffermüller, 1775) & + & + & - & - & - & + & + & - & - & + & + & - & ЗП \\
\hline 256 & H. strouhali Boursin, 1955 & - & + & + & - & - & - & - & - & - & - & - & - & CA \\
\hline 257 & Lasionhada proxima (Hübner, 1809) & - & $!$ & + & - & - & + & + & - & - & + & - & - & $\Pi$ \\
\hline 258 & L. orientalis (Alphéraky, 1882) & - & + & ! & + & - & + & + & + & - & + & + & + & CA \\
\hline 259 & Mythimna pudorina (Denis et Schiffermüller, 1775) & + & + & - & - & - & - & - & - & - & - & - & - & $\Pi$ \\
\hline 260 & M. conigera (Denis et Schiffermüller, 1775) & - & + & + & - & - & + & + & - & - & + & + & + & ЗП \\
\hline 261 & M. farrago (Fabricius, 1787) & - & + & - & - & - & + & - & - & - & + & - & - & ЗП \\
\hline 262 & M. pallens (Linnaeus, 1758) & - & - & - & - & - & + & + & - & - & - & - & - & ЗП \\
\hline 263 & M. dungana (Alphéraky, 1882) & - & $!$ & - & - & - & + & - & - & - & - & - & - & CA \\
\hline 264 & M. melania (Staudinger, 1889) & - & - & - & - & - & + & - & - & - & - & - & - & CA \\
\hline 265 & M. vitellina (Hübner, 1808) & + & + & + & - & + & $!$ & + & - & + & + & + & - & ЗП \\
\hline 266 & M. I-album (Linnaeus, 1767) & + & - & - & - & - & - & - & - & + & + & - & - & ЗП \\
\hline 267 & Leucania comma (Linnaeus, 1758) & - & + & - & - & - & - & - & - & - & - & - & - & ЗП \\
\hline 268 & Actebia fennica (Tauscher, 1806) & - & - & - & - & - & + & + & - & - & - & - & - & $\Gamma$ \\
\hline 269 & A. squalida (Guenee, 1852) & + & + & - & - & - & - & - & - & - & - & - & - & ВП \\
\hline 270 & A. confusa (Alphéraky, 1882) & - & + & + & - & - & - & - & - & - & + & - & - & ТШ \\
\hline 271 & A. ala (Staudinger, 1881) & - & - & - & - & - & - & - & - & + & - & - & - & ТШ \\
\hline 272 & Dichagyris musiva (Hübner, 1803) & - & + & - & - & - & + & - & - & - & - & - & - & $\Pi$ \\
\hline 273 & D. ulrici (Corti et Draudt, 1933) & - & - & - & - & - & + & + & - & - & - & - & - & ЦП \\
\hline 274 & D juldussi (Alphéraky, 1882) & - & $!$ & $!$ & - & - & $!$ & $!$ & - & - & + & + & - & ЦП \\
\hline 275 & D. flammatra (Denis et Schiffermüller, 1775) & + & + & - & - & ! & + & - & - & $!$ & $!$ & - & - & $\Pi$ \\
\hline 276 & D. vallesiaca (Boisduval, 1837) & + & + & - & - & + & $!$ & - & - & - & - & - & - & ЦП \\
\hline 277 & D. squalorum (Eversmann, 1856) & - & - & - & - & - & - & - & - & - & + & - & - & ЦП \\
\hline 278 & D. candelisequa (Denis et Schiffermüller, 1775) & + & $!$ & - & - & + & + & - & - & + & + & - & - & ЗП \\
\hline 279 & D. elbursica (Draudt, 1937) & - & - & - & - & - & + & + & - & - & - & - & - & CA \\
\hline 280 & D. grisescens (Staudinger, 1878) & - & - & - & - & - & + & + & - & - & - & - & - & ЦП \\
\hline 281 & D. leucomelas Brandt, 1941 & - & - & - & - & - & - & - & - & - & + & - & - & CA \\
\hline 282 & D. melanuroides Kozhantshikov, 1930 & + & - & - & - & - & - & - & - & + & - & - & - & CA \\
\hline 283 & D. jacobsoni Kozhantschikov, 1930 & - & - & - & - & - & + & + & - & - & - & - & - & ЦП \\
\hline 284 & D. hymalayensis Turati, 1933 & - & - & - & - & - & - & + & + & - & - & - & - & ЦП \\
\hline 285 & D. devota (Christoph, 1884) & - & - & - & - & - & - & - & - & + & + & - & - & ЦП \\
\hline 286 & D. clara (Staudinger, 1888) & - & - & - & - & + & + & - & - & + & - & - & - & ТШ \\
\hline 287 & D. umbrifera (Alphéraky, 1882) & - & - & - & - & $!$ & $!$ & - & - & + & + & - & - & ТШ \\
\hline 288 & D. lutescens (Eversmann, 1844) & - & - & - & - & - & + & - & - & - & - & - & - & ЦП \\
\hline 289 & D. forficula (Eversmann, 1851) & - & - & - & - & + & + & + & - & - & - & - & - & ЦП \\
\hline 290 & D. disturbans (Püngeler, 1914) & - & - & - & - & + & + & - & - & - & - & - & - & ЦП \\
\hline 291 & D. perturbans (Boursin, 1948) & - & - & - & - & - & - & + & - & - & - & - & - & CA \\
\hline 292 & D. acutijuxta (Boursin, 1957) & - & - & - & - & + & + & + & - & - & - & - & - & CA \\
\hline 293 & D. exacta (Staudinger, 1888) & - & - & - & - & - & + & - & - & - & - & - & - & ТШ \\
\hline 294 & D. orientis (Alphéraky, 1882) & - & - & - & - & + & $!$ & + & - & + & + & + & - & ЦП \\
\hline 295 & Euxoa conspicua (Hübner, 1824) & + & + & - & - & + & + & - & - & + & $!$ & - & - & ЗП \\
\hline 296 & E. ochrogaster (Guenée, 1852) & - & - & - & - & - & + & $!$ & - & - & + & + & - & $\Gamma$ \\
\hline 297 & E. flavisignata Corti, 1932 & - & - & - & - & - & - & - & - & - & + & $!$ & - & ЦП \\
\hline 298 & E. distinguenda (Lederer, 1857) & - & - & - & - & - & - & - & - & - & + & - & - & ЗП \\
\hline 299 & E. tritici (Linnaeus, 1761) & + & + & - & - & - & - & - & - & - & - & - & - & ЗП \\
\hline 300 & E. enixa Püngeler, 1906 & - & - & - & - & - & + & - & - & - & + & - & - & ТШ \\
\hline 301 & E. aquilina (Denis et Schiffermüller, 1775) & + & + & - & - & - & - & - & - & - & - & - & - & $\Pi$ \\
\hline 302 & E. bogdanovi (Erschoff, 1874) & + & + & - & - & - & - & - & - & + & + & - & - & CA \\
\hline 303 & E. mustelina (Christoph, 1877) & - & - & - & - & - & + & ! & - & - & + & - & - & ЦП \\
\hline 304 & E. hypochlora Boursin, 1964 & - & - & - & - & - & + & - & - & - & - & - & - & CA \\
\hline 305 & E. subconspicua (Staudinger, 1888) & - & - & - & - & - & + & + & - & - & - & - & - & CA \\
\hline 306 & E. impexa Püngeler, 1904 & - & - & - & - & - & + & - & - & - & + & - & - & ТШ \\
\hline 307 & E. hilaris (Freyer, 1838) & - & - & - & - & - & - & + & - & - & - & $!$ & - & ЦП \\
\hline 308 & Heliophobus texturata (Alpheraky, 1892) & - & - & + & $!$ & - & - & - & - & - & - & - & - & CA \\
\hline 309 & Trichosilia plumbea (Alphéraky, 1887) & - & + & - & - & - & + & - & - & - & - & - & - & CA \\
\hline 310 & Agrotis bigramma (Esper, 1790) & + & - & - & - & - & - & - & - & - & - & - & - & ЦП \\
\hline 311 & A. exclamationis (Linnaeus, 1758) & + & + & + & + & + & $!$ & + & + & + & + & + & + & $\Pi$ \\
\hline 312 & A. segetum (Denis et Schiffermüller, 1775) & + & $!$ & - & - & + & + & - & - & + & + & + & - & K \\
\hline 313 & A. turbans Staudinger, 1888 & ! & - & - & - & - & - & - & - & - & - & - & - & CA \\
\hline 314 & Diarsia obuncula (Hampson, 1903) & - & - & - & - & - & - & + & - & - & - & + & $!$ & ЦП \\
\hline 315 & Cerastis rubricosa (Denis et Schiffermüller, 1775) & + & - & - & - & - & - & - & - & - & - & - & - & $\Pi$ \\
\hline 316 & Ammogrotis suavis (Staudinger, 1896) & - & - & - & - & - & + & + & - & - & + & - & - & ЦП \\
\hline
\end{tabular}


Korb, S.K. Analysis of the vertical distribution of the Noctuoid moths.... Acta Biologica Sibirica, 2018, 4(3), 130-143

\begin{tabular}{|c|c|c|c|c|c|c|c|c|c|c|c|c|c|c|}
\hline 317 & Eicomorpha antiqua Staudinger, 1888 & $!$ & + & - & - & + & + & - & - & - & + & - & - & CA \\
\hline 318 & E. koeppeni Alphéraky, 1894 & - & - & - & - & - & - & - & - & + & + & - & - & CA \\
\hline 319 & Standfussiana socors (Corti, 1925) & - & + & - & - & - & - & - & - & - & - & - & - & ТШ \\
\hline 320 & Rhyacia simulans (Hufnagel, 1766) & + & $!$ & + & - & - & - & - & - & - & - & - & - & ЗП \\
\hline 321 & R. similis (Staudinger, 1888) & - & + & + & - & - & - & - & - & - & - & - & - & ТШ \\
\hline 322 & R. subdecora (Staudinger, 1888) & - & - & - & - & - & + & + & - & - & - & - & - & CA \\
\hline 323 & R. junonia (Staudinger, 1881) & - & + & + & - & - & + & + & - & - & + & + & - & ЦП \\
\hline 324 & Chersotis acutangula (Staudinger, 1892) & - & - & + & + & - & - & + & $!$ & - & - & - & - & CA \\
\hline 325 & C. sordescens (Staudinger, 1900) & - & - & $!$ & - & - & + & + & - & - & + & - & - & CA \\
\hline 326 & C. transiens (Staudinger, 1897) & + & + & $!$ & - & + & + & $!$ & - & + & + & + & - & ВП \\
\hline 327 & C. vicina (Corti, 1930) & + & + & - & - & + & + & - & - & - & - & - & - & ТШ \\
\hline 328 & Noctua orbona (Hufnagel, 1766) & + & + & + & - & + & + & - & - & + & $!$ & - & - & ЗП \\
\hline 329 & Spaelotis ravida (Denis et Schiffermüller, 1775) & - & - & - & - & - & + & - & - & - & + & - & - & $\Pi$ \\
\hline 330 & S. defuncta (Staudinger, 1896) & - & + & + & - & - & + & + & - & - & - & - & - & ЦП \\
\hline 331 & S. deplorata (Staudinger, 1896) & - & + & + & - & - & - & - & - & - & - & - & - & CA \\
\hline 332 & Eurois occulta (Linnaeus, 1758) & + & + & + & + & + & + & + & + & + & + & + & + & \ulcorner \\
\hline 333 & Opigena polygona (Denis et Schiffermüller, 1775) & - & - & - & - & - & + & - & - & - & + & - & - & $\Pi$ \\
\hline 334 & Anaplectoides prasina (Denis et Schiffermüller, 1775) & - & - & - & - & - & - & - & - & - & + & + & - & $\Gamma$ \\
\hline 335 & Xestia baja (Denis et Schiffermüller, 1775) & + & + & - & - & + & + & - & - & - & - & - & - & $\Pi$ \\
\hline 336 & X. xanthographa (Denis et Schiffermüller, 1775) & + & - & - & - & - & - & - & - & - & - & - & - & $\Gamma$ \\
\hline 337 & X. erschoffi (Staudinger, 1897) & - & - & - & - & - & $!$ & + & - & - & + & + & - & CA \\
\hline 338 & X. c-nigrum (Linnaeus, 1758) & + & ! & - & - & - & - & - & - & - & - & - & - & $\Gamma$ \\
\hline 339 & Eugnorisma gaurax (Püngeler, 1900) & - & - & - & - & - & + & + & - & - & - & - & - & ТШ \\
\hline 340 & E. trigonica (Alphéraky, 1882) & + & + & $!$ & - & + & + & + & - & + & + & + & - & CA \\
\hline 341 & E. insignata (Lederer, 1853) & + & + & - & - & - & - & - & - & + & + & - & - & ЦП \\
\hline 342 & Eugraphe ornata (Staudinger, 1892) & - & - & - & - & - & + & - & - & - & - & - & - & CA \\
\hline 343 & E. funkei (Püngeler, 1901) & - & - & - & - & - & - & - & - & - & + & - & - & $\mathrm{CA}$ \\
\hline 344 & E. senescens (Staudinger, 1881) & + & + & - & - & - & - & - & - & - & - & - & - & CA \\
\hline 345 & Isochlora viridis Staudinger, 1882 & - & - & - & - & - & - & + & $!$ & - & - & - & - & CA \\
\hline \multirow[t]{2}{*}{346} & I. viridissima Staudinger, 1882 & - & + & + & - & - & + & + & $!$ & - & + & + & + & CA \\
\hline & Иmoго & 134 & 114 & 52 & 9 & 85 & 191 & 96 & 17 & 93 & 125 & 50 & 12 & \\
\hline
\end{tabular}

Расшифровка в столбце «Тип ареала»: ВП - восточнопалеарктический, Г - голарктический, ЗП западнопалеарктический, К - космополитический, П - палеарктический, СА - среднеазиатский, ТШ - тянь-шаньский, ЦП - центральнопалеарктический. Плюс (+) - вид отмечен для данного пояса; восклицательный знак (!) - вид в данном поясе является массовым.

Важно отметить, что исследованы только центральные части указанных хребтов, и данные и последующие выводы справедливы только для них и обсуждаются только для них.

На Киргизском хр. отмечено 246 видов ноктуоидных чешуекрылых, на хр. Джумгалтоо - 210 видов, на Ферганском хр. 164 вида. Сравнение фаун совкообразных чешуекрылых этих хребтов по мере сходства (коэффициент Жаккара, далее К) показало, что эти фауны несходны: К хр. Киргизский и Джумгалтоо составляет 40,3\%, К хр. Киргизский и Ферганский составляет 37,6\%, К хр. Джумгалтоо и Ферганский составляет 46,7\% (фауны считаются сходными, если К равен или больше 50,0\%). Фауны ноктуоидных чешуекрылых Ферганского хр. и хр. Джумгалтоо, исходя из этих значений, ближе, чем любая из этих фаун и фауна Киргизского хр. Заметим, что для булавоусых чешуекрылых нами были получены противоположные результаты: все три фауны сходны (Korb, 2005).

При сравнении поясных фаун исследованных хребтов получаются примерно такие же результаты, что и при сравнении фаун в целом, за исключением того, что низкогорные фауны ноктуоидных чешуекрылых хр. Ферганский и Джумгалтоо сходны (К=51,7\%). Низкогорные фауны хр. Киргизский и Джумгалтоо и хр. Киргизский и Ферганский несходны (К=41,3\% и К=42,9\% соответственно); среднегорные фауны Noctuoidea указанных хребтов несходны (К=47,6\% для пары Киргизский хр. - Джумгалтоо; К= 44,1\% для пары Ферганский хр. - Джумгалтоо; К=36,1\% для пары Киргизский хр. - Ферганский хр.), высокогорные несходны (К=34,4\% для пары Киргизский хр. Джумгалтоо; К= 40,0\% для пары Ферганский хр. - Джумгалтоо; К=25,7\% для пары Киргизский хр. - Ферганский хр.); сверхвысокогорные несходны (К=34,8\% для пары Киргизский хр. - Джумгалтоо; К= 45,0\% для пары Ферганский хр. - Джумгалтоо; К=36,8\% для пары Киргизский хр. - Ферганский хр.).

На рис. 1 приводится дендрограмма сходства фаун ноктуоидных чешуекрылых вертикальных поясов обследованных хребтов. Дендрограмма полностью подтверждает предложенную нами для дневных бабочек (Korb, 2012) схему вертикальной поясности гор Средней Азии: отдельными кластерами выделяются низкогорья, среднегорья, высокогорья и сверхвысокогорья, причем последний кластер на дендрограмме обособлен, что подтверждает наши выводы о независимом происхождении сверхвысокогорной фауны и о ее малых связях с фаунами чешуекрылых расположенных ниже поясов. 


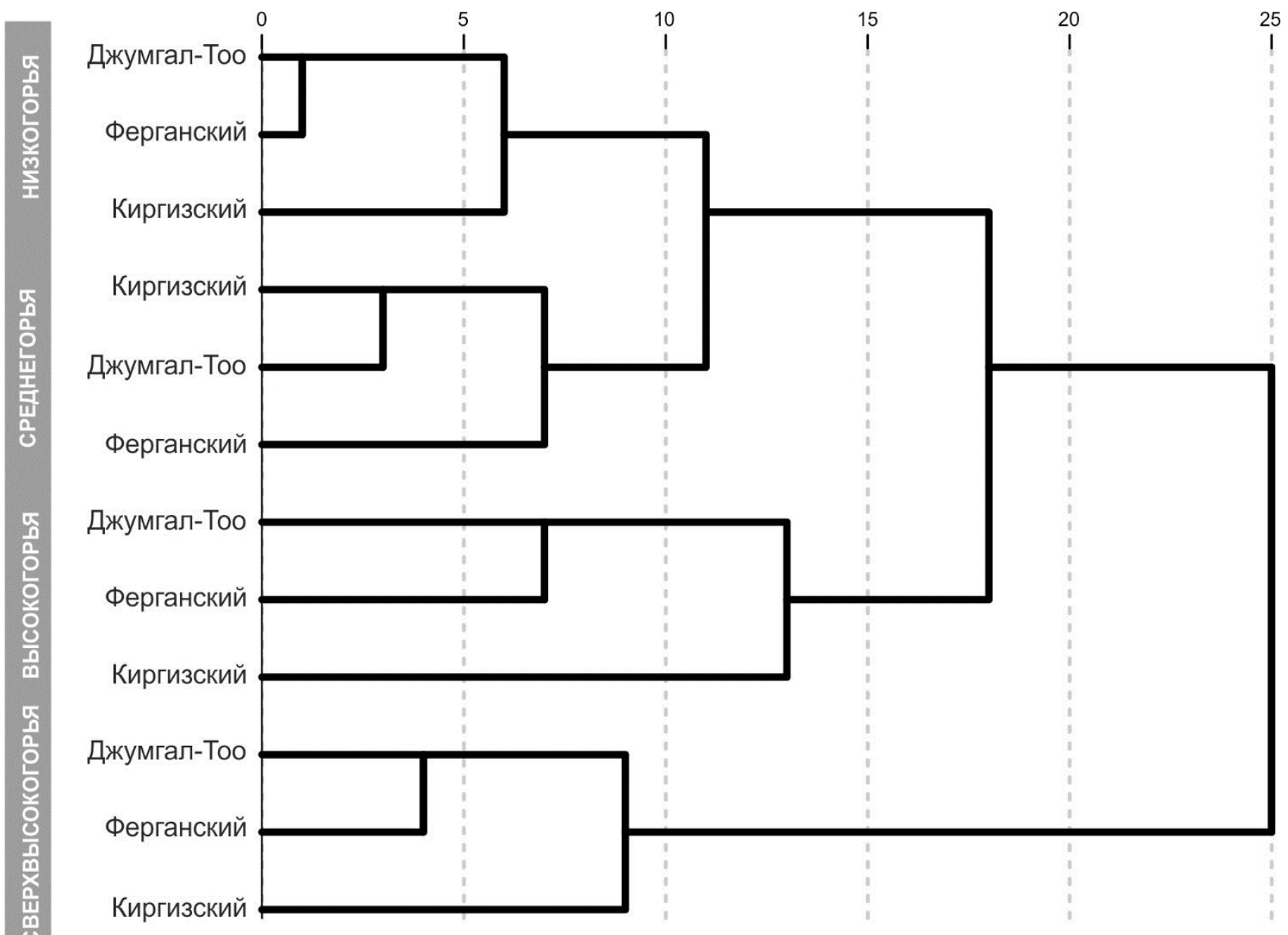

Рис. 1. Дендрограмма сходства фаун ноктуоидных чешуекрылых вертикальных поясов Северного, Внутреннего и Западного Тянь-Шаня (метод: ближайшего соседа; бинарное сходство (коэффициент Жаккара)).

Низкогорный пояс. Наиболее богат видами на Киргизском хр., наименее - на хр. Джумгалтоо; Ферганский хр. занимает между ними промежуточное положение. Высокое видовое богатство в низкогорном поясе Киргизского хр. объясняется его географическим положением: северный макросклон, на котором производились исследования, граничит с обширными среднеазиатскими пустынями и имеет серьезное влияние фаун этих пустынь. Ферганский хр. с востока также граничит с пустынями Средней Азии, однако область этого контакта относительно невелика (для Киргизского хр. это практически весь северный макросклон, для Ферганского хр. только центральная часть его западного склона) поэтому влияние пустынных фаун на низкогорный пояс Ферганского хр. не так велико, как на Киргизском хр. Ядро фауны ноктуоидных чешуекрылых низкогорий Киргизского хр. составляют: Lacydes spectabilis, Eudiaphora turensis, Phragmatobia fuliginosa, Autophila asiatica, Apopestes phantasma, Drasteria picta, Armada clio, Dismylichia bicyclica, Caradrina albina, C. fergana, Episema lederi, Eremohadena immunda, Agrotis turbans, Eicomorpha antiqua. Отмеченный только на Киргизском хр. Phidrimana amurensis является видом, активно расселяющимся на восток, что неоднократно отмечалось в современной литературе (Knyazev et al., 2010, 2012; Matov, Anikn, 2012). Ядро фауны низкогорного пояса хр. Джумгалтоо составляют Dicallomera fascelina, Lacydes spectabilis, Eudiaphora turensis, Phragmatobia fuliginosa, Drasteria rada, Acontia trabealis, Tyta luctuosa, Calophasia lunula, Protoschinia scutosa, Caradrina fergana, Dichagyris flammatra, D. umbrifera. Ядро фауны низкогорного пояса Ферганского хр. составляют Phragmatobia fuliginosa, Autophila asiatica, Odice arcuinna, Clytie gracilis, Raphia approximata, Helicoverpa armigera, Caradrina clavipalpis, Lacanobia w-latinum, Hadena albimacula, Dichagyris flammatra.

Таким образом, для Северного Тянь-Шаня в низкогорном поясе характерны виды туранского и близкого распространения, во Внутреннем Тянь-Шане происходит значительное добавление западнопалеарктических элементов, в Западном Тянь-Шане западнопалеарктические элементы составляют уже большинство характерных видов.

Среднегорный пояс. Наиболее богат видами на хр. Джумгалтоо, наименее - на Киргизском хр.; Ферганский хр. занимает промежуточное положение. Высокое видовое богатство в хр. Джумгалтоо объясняется его географическим положением: находясь на стыке Северного и Западного Тянь-Шаня, эта часть Внутреннего ТяньШаня испытывает фаунистическое влияние указанных регионов, фауна ноктуоидных чешуекрылых среднегорного пояса хр. Джумгалтоо обогащена как северотяншанскими, так и западнотяншанскими элементами. 
Korb, S.K. Analysis of the vertical distribution of the Noctuoid moths.... Acta Biologica Sibirica, 2018, 4(3), 130-143

Для среднегорного пояса Киргизского хр. характерны следующие виды: Arctia intercalaris, Chelis strigulosa, Lygephila craccae, Drasteria obscurata, D. caucasica, Autographa gamma, Acontia lucida, Tyta luctuosa, Shargacucullia verbasci, Caradrina albina, Hoplodrina octogenaria, Auchmis detersina, Apamea ferrago, Anarta trifolii, Lacanobia suasa, Lasionhada proxima, Mythimna dungana, Dichagyris juldussi, D. candelisequa, Agrotis segetum, Rhyacia simulans, Xestia c-nigrum. Для среднегорного пояса хр. Джумгалтоо характерны следующие виды: Clostera modesta, Dicallomera fascelina, Arctia caja, Manulea complana, Eublemma conistrota, Odice arcuinna, Drasteria sesquilina, Polychrysia esmeralda, Autographa gamma, Acontia trabealis, Lophoterges centralasiae, Bryoxena centralasiae, Cryphia distincta, Hoplodrina levis, Argyrospila succinea, Protarchanara mythimnoida, Apamea furva, Anarta dianthi, A. trifolii, Polia bombycina, Lacanobia suasa, Mamestra brassicae, Conisania vidua, Hecatera bicolorata, Mythimna vitellina, D juldussi, Dichagyris vallesiaca, D. umbrifera, D. orientis, Agrotis exclamationis, Xestia erschoffi. Для среднегорного пояса Ферганского хр. характерны: Euproctis karghalica, Leucoma salicis, Lymantria dispar, Drasteria caucasica, Acontia trabealis, Tyta luctuosa, Bryoxena centralasiae, Hoplodrina levis, Amphipoea fucosa, Cosmia subtilis, Anarta trifolii, Lacanobia suasa, Mamestra brassicae, Conisania leineri, Dichagyris flammatra, Euxoa conspicua, Noctua orbona.

Таким образом, для всех трех хребтов в составе характерных видов подавляющее большинство - виды с широким палеарктическим или среднеазиатским распространением.

Высокогорный пояс. На Киргизском и Ферганском хр. фауны высокогорных поясов примерно одинаковы по числу видов (52 и 51 соответственно), а вот на хр. Джумгалтоо эта фауна почти в два раза богаче двух других. Высокое видовое богатство в высокогорном поясе хр. Джумгалтоо объясняется его географическим положением: находясь на стыке Северного и Западного Тянь-Шаня, эта часть Внутреннего Тянь-Шаня испытывает фаунистическое влияние обоих регионов, фауна ноктуоидных чешуекрылых данного вертикального пояса хр. Джумгалтоо обогащена как северотяншанскими, так и западнотяншанскими элементами.

Для высокогорного пояса Киргизского хр. характерны: Euchalcia herrichi, Diachrysia chrysitis, Bryoxena centralasiae, Apamea furva, Haderonia arschanica, Lasionhada orientalis, Dichagyris juldussi, Chersotis sordescens, C. transiens, Eugnorisma trigonica. Для высокогорного пояса хр. Джумгалтоо характерны следующие виды ноктуоидных чешуекрылых: Zekelita diagonalis, Lygephila ludicra, Polychrysia esmeralda, Autographa monogramma, Cucullia splendida, Bryopolia chameleon, Bryoxena centralasiae, Bryophila miltophaea, Apamea furva, Cosmia ledereri, Haderonia arschanica, Polia serratilinea, Hecatera bicolorata, Hadena karagaia, Dichagyris juldussi, Euxoa ochrogaster, E. mustelina, Chersotis transiens. Для высокогорного пояса Ферганского хр. характерны: Bryoxena centralasiae, Cryphia rueckbeili, Phoebophilus amoenus, Cosmia subtilis, Conisania leineri, Euxoa flavisignata, E. hilaris.

Таким образом, для всех трех хребтов в составе характерных видов подавляющее большинство - виды со среднеазиатским или более узким тяньшаньским распространением.

Сверхвысокогорный пояс. Самой бедной фауной ноктуоидных чешуекрылых этого пояса оказалась фауна Киргизского хр. (9 видов), самой богатой - хр. Джумгалтоо (17 видов). Фауна Ферганского хр. по количеству видов занимает промежуточное положение.

Характерные виды сверхвысокогорной фауны Киргизского хр.: Hypsophila jugorum, Heliophobus texturata. Характерные виды сверхвысокогорной фауны хр. Джумгалтоо: Cerapteryx megala, Chersotis acutangula, Isochlora viridis, l. viridissima. Характерные виды сверхвысокогорной фауны Ферганского хр.: Hypsophila jugorum, Diarsia obuncula.

Таким образом, ядро сверхвысокогорных фаун указанных хребтов составляют исключительно виды среднеазиатского распространения.

Ареалогическая структура фауны включает 8 типов ареалов (табл. 1), объединенных в 2 комплекса: комплекс обширных ареалов и комплекс среднеазиатских ареалов. Распределение видов по типам и комплексам приводим на рис. 2-4.

Следует оговориться, что на текущем этапе исследований нами использована весьма примитивная в своей укрупненности ареалогическая модель; проблема среднеазиатской фауны ноктуоидных (да и вообще, ночных) чешуекрылых заключается в ее очень слабой изученности. Сборы ноктуоидных чешуекрылых, за исключением немногих, из этого региона весьма нерегулярны, количество представленных в них видов невелико. Достаточно указать на то, что классическая работа по ноктуоидным чешуекрылым Киргизии, опубликованная в конце прошлого века (что само по себе уже нонсенс) содержит сведения о примерно вполовину меньшем количестве видов, известных по работе, опубликованной всего лишь 30 годами позднеe (Nekrasov et al., 1998; Korb et al., [2016]). Именно по этой причине использовать подробное ареалогическое деление не имеет смысла: многие виды распространены в Средней Азии гораздо шире, чем представлялось ранее, и постоянная корректировка типов их ареалов не имеет смысла.

В общем фауна сравниваемых фаун целиком (рис. 2, 1) и отдельных хребтов (рис 2, 2-4) на 60\% состоит из видов с обширным распространением и на 40\% - из видов со среднеазиатским распространением. Ареалогически фауны обследованных хребтов весьма сходны.

В фаунах низкогорных поясов обследованных хребтов преобладание видов с обширным распространением на Ферганском хр. составляет 73\%, на хр. Джумгалтоо - 74\%, на Киргизском хр. доля видов с обширными ареалами в указанном поясе составляет 76\% (рис. 3, 1-3). В фаунах среднегорий процент видов с обширным распространением меньше, чем в фаунах низкогорий (рис. 3, 4-6) и примерно одинаков для всех хребтов. В 
высокогорных и сверхвысокогорных поясах обследованных хребтов доля видов с обширным распространением еще меньше, чем в фаунах среднегорий и низкогорий, и приближается к 50\% (рис. 4). На фоне сверхвысокогорных фаун Ферганского хр. и хр. Джумгалтоо сильно выделяется явно обедненная фауна сверхвысокогорий Киргизского хр.: доля видов с обширными ареалами здесь составляет всего 30\% (рис. 4, 4).
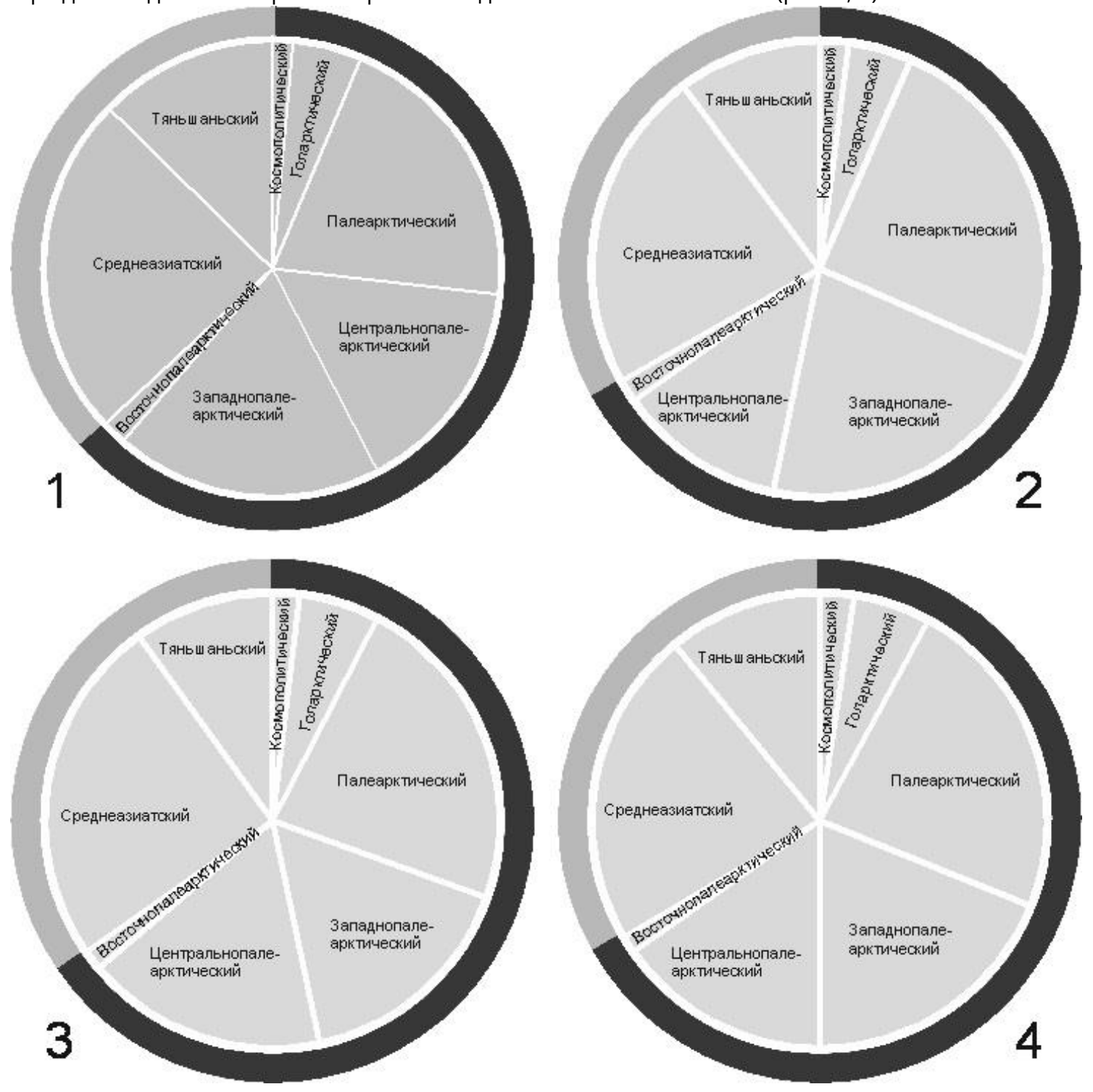

Рис. 2. Структура ареалов сравниваемых горных хребтов: вся зарегистрированная фауна (1) и отдельно Киргизский хр. (2), хр. Джумгалтоо (3) и Ферганский хр. (4). Сектора - типы ареалов. Внутренний круг - комплексы ареалов.

\section{Выводы}

1. Впервые проведен анализ вертикального распределения ноктуоидных чешуекрылых центральных частей хребтов Киргизского, Джумгалтоо и Ферганского, представляющих разные орографические регионы.

2. Вертикальное распределение ноктуоидных чешуекрылых обследованного района совпадает с ранее выясненным вертикальным распределением булавоусых чешуекрылых.

3. В отличие от дневных бабочек, фауны ноктуоидных чешуекрылых вертикальных поясов обследованных хребтов Северного, Внутреннего и Западного Тянь-Шаня, за исключением низкогорий хр. Джумгалтоо и Ферганского, несходны.

4. Для Noctuoidea данного региона, также как для Rhopalocera, характерно увеличение доли видов среднеазиатского распространения при движении вверх из пояса в пояс.

5. Подтверждается показанная для булавоусых чешуекрылых гипотеза об автохтонном происхождении сверхвысокогорной вертикальной фауны.

6. Предварительно показано, что обследованные фауны состоят из видов с 8 типами ареалов, объединенных в 2 комплекса (обширных ареалов и среднеазиатский). 

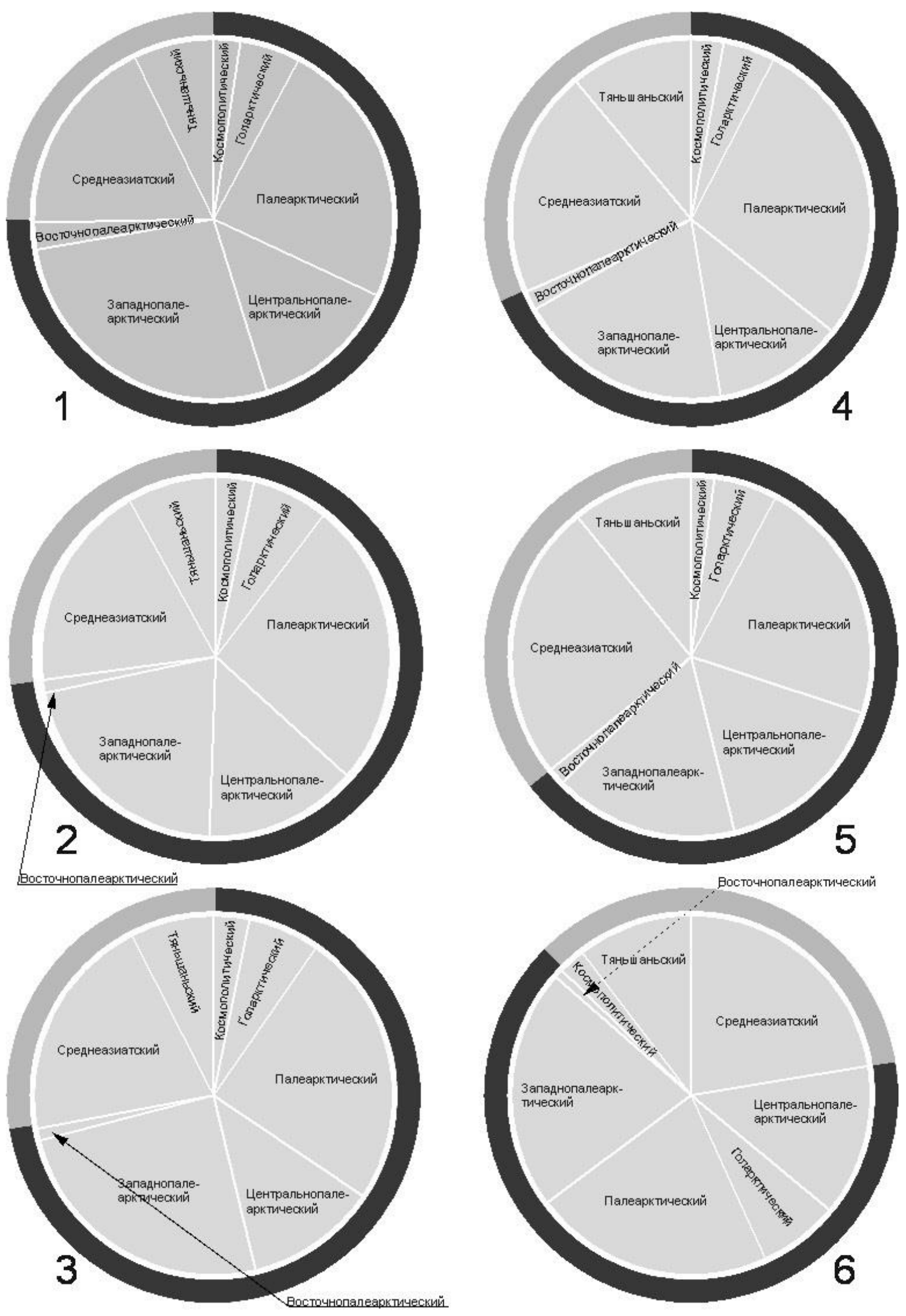

Рис. 3. Структура ареалов низкогорных поясов Киргизского хр. (1), хр. Джумгалтоо (2) и Ферганского хр. (3) и среднегорных поясов Киргизского хр. (4), хр. Джумгалтоо (5) и Ферганского хр. (6). Сектора - типы ареалов. Внутренний круг - комплексы ареалов. 

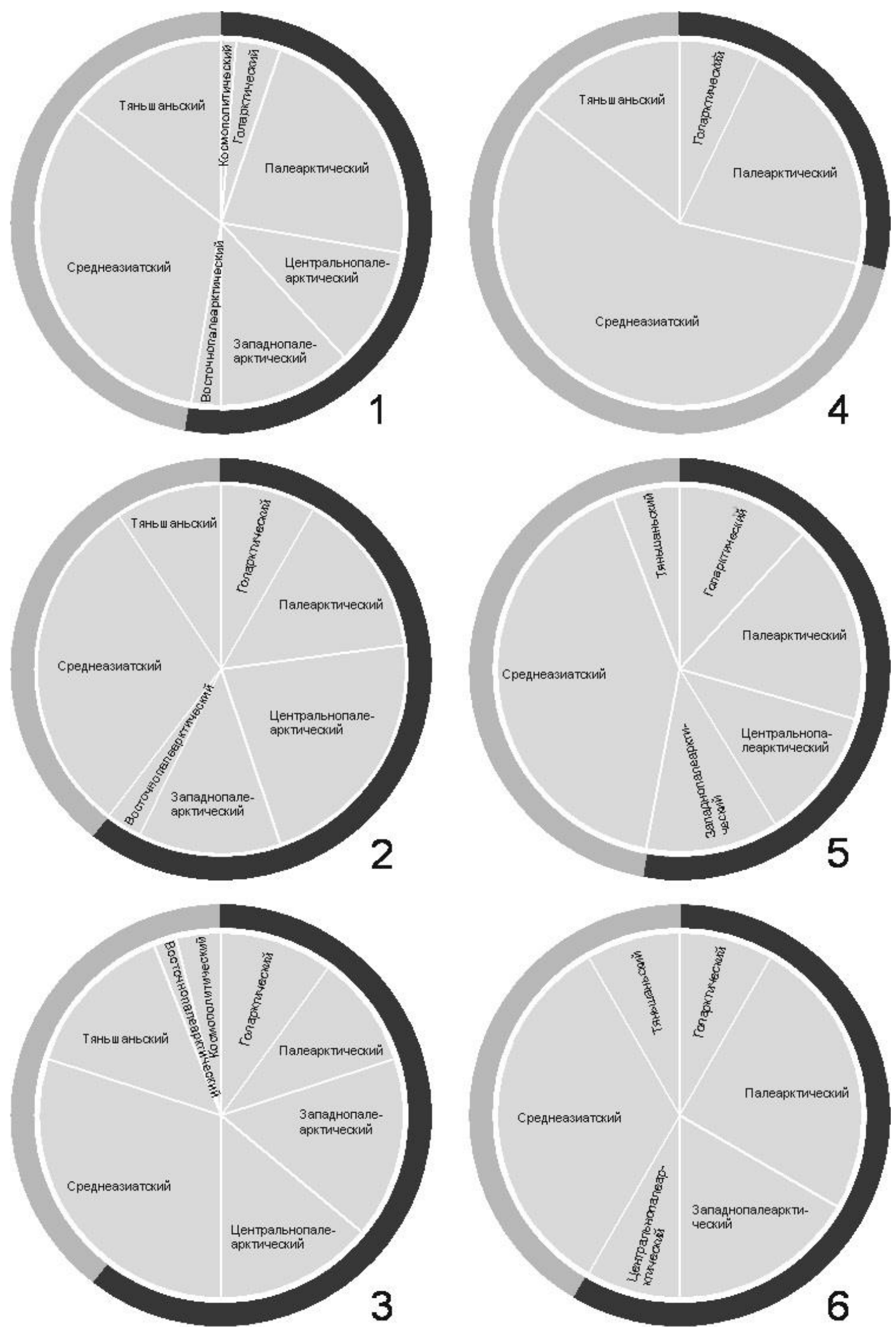

Рис. 4. Структура ареалов высокогорных поясов Киргизского хр. (1), хр. Джумгалтоо (2) и Ферганского хр. (3) и сверхавслокогорных поясов Киргизского хр. (4), хр. Джумгалтоо (5) и Ферганского хр. (6). Сектора - типы ареалов. Внутренний круг - комплексы ареалов. 


\section{References}

Capinera, J.L. (2001). Handbook of vegetable pests. San Diego, San Francisco, New York, Boston, London, Sydney, Tokyo: Academic Press. 650 p.

Fibiger, M., László, G.M., Ronkay, G., Ronkay, L., Speidel, W., Varga, Z., Wahlberg, N., Witt, T.J., Yela, J.L., Zahiri, R., Zilli, A. (2011). Lymantriinae and Arctiinae including phylogeny and checklist of the Quadrifid Noctuoidea of Europe. Noctuidae Europaeae. Vol. 13. Sorø: Entomological Press. 448 p.

Fry, R., Waring, P. (1996). A guide to moth traps and their use. The Amateur Entomologist, 24, 1-60.

Knyazev, S.A., Dubatolov, V.V., Ponomaryov, K.B., Tepluokhov, V.Y., Kholodov, O.N., Rogalev, V.V., Maranik, V.V. (2010). Owlet mots (Lepidoptera, Noctuidae) of the Omsk Province. Amurian zoological Journal, 2 (2), 148-183 (in Russian).

Knyazev, S.A., Pekarsky, O.N., Marusov, A.A. (2012). New records of Phidrimana amurensis (Staudinger, 1892) (Lepidoptera: Noctuidae) in the European part of Russia. Eversmannia, 29-30, 91 (in Russian).

Korb, S.K. (2012). Zoogeographical analysis of the vertical structure of the butterfly fauna of the North Tian-Shan (Lepidoptera: Rhopalocera) and the questions of the faunagenesis of the Middle Asia. Caucasian Entomological Bulletin, 8 (2), 283-296 (in Russian).

Korb, S.K. (2005). Genesis der Tagfalterfauna Bergmittelasiens: Analyse, Problemen, Rekonstruktion. Nischnij Novgorod: Korb Verlag. $168 \mathrm{~S}$.

Korb, S.K., Matov, A.Y. (2016). Vertical distribution of the Noctuoid moths in the central part of Kirgizsky mountain ridge (North Tian-Shan) (Lepidoptera: Noctuoidea). Eversmannia, 45-46, 68-72 (in Russian).

Matov, A.Y., Anikin, V.V. (2012). Additions to the owlet moths fauna (Lepidoptera, Noctuidae) of the Khvalynsk National Park in the Saratov Province. Entomological and parasitological research in the Volga region, 12, $22-25$ (in Russian).

Nekrasov, A.V., Poltavsky, A.N., Rybin, S.N. (1988). Owlet moths (Lepidoptera, Noctuidae) of the Kirgiz Soviet Socialistic Republic. Entomological research in Kirgizia, Frunze, Ilim, 27-61 (in Russian).

Steshetkin, Y.Y. (1981). Analysis of the subalpine fauna of butterflies (Lepidoptera, Rhopalocera) of the central part of the Peter the Great mountain ridge. Zoological Journal, 60 (6), 856-865.

\section{Citation:}

Korb, S.K. (2018). Comparative analysis of the vertical distribution of the Noctuoid moths (Lepidoptera) within the central parts of the mountain ridges Kirgizsky, Dzhumgaltoo and Fergansky: preliminary results. Acta Biologica Sibirica, 4 (3), 130-143.

Submitted: 11.07.2018. Accepted: 01.09.2018

cross ref http://dx.doi.org/10.14258/abs.v4i3.4418

(C) 2018 by the authors. Submitted for possible open access publication under the terms and conditions of the Creative Commons Attribution (CC BY) license (http://creativecommons.org/licenses/by/4.0/). 